\title{
Viral Süperantijenler*
}

\author{
Viral Superantigens
}

\section{A. Dürdal US}

Hacettepe Üniversitesi Tıp Fakültesi, Tıbbi Mikrobiyoloji Anabilim Dalı (E), Ankara. Hacettepe University Faculty of Medicine, Department of Medical Microbiology (Ret), Ankara, Turkey.

*1. Ulusal Viroloji Günleri ve Kursu (25-28 şubat 2016, Ankara) kongresinde konferans olarak sunulmuştur.

Geliş Tarihi (Received): 24.02.2016 • Kabul Ediliş Tarihi (Accepted): 08.03.2016

\section{öz}

Süperantijenler, çeşitli mikroorganizmalar tarafından üretilen ve $\mathrm{T}$ hücrelerini olağandışı yolla, poliklonal olarak, güçlü ve hızlı bir şekilde aktive eden mikrobiyal proteinlerdir. Bir süperantijen (SAg)'in T hücrelerini uyarması, T hücre reseptörü (TCR)'nün belirli bir değişsen-beta (V $\beta$ ) bölgesi ile antijen sunan hücrelerin yüzeyindeki MHC sınıf II molekülüne, işlenmeye gerek duymaksızın, dışarıdan köprü oluşturarak, özgül olmayan şekilde bağlanmasıyla olur. SAg'ler; 1) ekzojen (mikroorganizmalar tarafından salgılanan çözünür protein ve ekzotoksinler), 2) endojen (hücre genomuna entegre olmuş viruslar tarafından kodlanan transmembran proteinler) ve 3) B hücre SAg'leri (predominant olarak B hücrelerini uyaran proteinler) olmak üzere üç grupta sınıflandırılır. En iyi tanımlanan ve üzerinde en çok çalışılan SAg'ler, stafilokokal ve streptokokal ekzotoksinlerdir; ancak diğer birçok mikroorganizmanın da SAg aktivitesine sahip olduğu bilinmektedir. İnsanda ciddi enfeksiyonlara yol açan çeşitli virusların varlığına rağmen, patogenezinde, SAg özelliği gösteren proteinlerin tanımlandığı virus sayısı ise görece olarak azdır. Bugüne dek SAg kodladığı belirlenen viruslar; fare meme tümörü virusu (MMTV) (Marrack ve ark., 1991), kuduz virusu (Lafon ve ark., 1992), Epstein-Barr virusu (EBV) (Sutkowski ve ark., 1996), insan endojen retrovirusu (human endogenous retrovirus; HERV) (Conrad ve ark., 1997), insan immün yetmezlik virusu (HIV) (Posnett ve ark., 1995; Torres ve ark., 1996; Townsley-Fuchs ve ark., 1997) ve Ebola virus (Leroy ve ark., 2011) olarak sıralanabilir. SAg aktivitesine sahip olduğu ilk tanımlanan virus MMTV'dir. B tipi polimorfik bir retrovirus olan MMTV'nin, ekzojen (süt ile bulaşan replikatif form) ve endojen (kalıtsal geçiş gösteren proviral form) olmak üzere iki formu vardır ve her ikisi de SAg kodlamaktadır. Ekzojen MMTV'nin SAg'si, T hücrelerinin masif aktivasyonuna yol açarak, virusun bağırsaklardan meme dokusuna geçişini, dolayısıyla da yayılımını sağlar. Diğer taraftan endojen SAg'lerin ekspresyonu, fötal dönemde timusta öztoleransı indükleyerek, reaktif T hücrelerinin (Vß6-9 TCR taşıyan) delesyonuna yol açar ve böylece konağı, ilerideki ekzojen MMTV enfeksiyonundan korur. Kuduz virusunun kodladığı SAg, nükleokapsid yapısında bulunan N proteinidir ve TCR V $\beta 8$ taşıyan T hücrelerini uyarmaktadır. Sonuçta oluşan poliklonal T hücre aktivasyonu, özgül immün yanıtın kapatılmasına, virusun ilk enfeksiyon bölgesinden (kas dokusu) sinir 
uçlarına geçişinin kolaylaşmasına ve immünopatogenezin artışına yol açar. TCR V $\beta 13$ taşıyan T hücrelerini aktive eden EBV ile ilişkili SAg'nin ise, virusun kendisi tarafından değil, EBV latent membran proteinleri tarafından transaktive edilen, HERV-K18'in env geni tarafından kodlandığı gösterilmiştir (Sutkowski ve ark., 2001). EBV'nin indüklediği SAg üretiminin, virusun bellek B hücrelerinde latent olarak kalmasında ve ayrıca otoimmün hastalıklar ve onkogenez mekanizmalarında rol oynadığı ifade edilmektedir. HIV'in SAg'leri olarak tanımlanan proteinler ise Nef ve gp120'dir. Enfeksiyonun erken döneminde, dinlenme halindeki $C D 4^{+} \mathrm{T}$ hücrelerindeki (seçici olarak $\mathrm{V} \beta 12^{+}, \mathrm{V} \beta 5.3^{+}, \mathrm{V} \beta 18^{+} \mathrm{TCR}$ taşıyanlar) masif aktivasyonunun; ileri dönemlerde de, klonal delesyon, anerji ve enfekte olmayan $\mathrm{T}$ hücrelerindeki apoptozun, diğer mekanizmaların yanı sıra, Nef'in SAg özelliğinden kaynaklanabileceği düşünülmektedir. Buna karşın Nef'in SAg gibi davranmadığını ileri süren çalışmalar da vardır (Lapatschek ve ark., 2001). HIV'in gp120 proteini ise bir B hücre SAg olup, VH3 eksprese eden B hücre reseptörlerine bağlanarak poliklonal B hücre aktivasyonuna yol açar. Ayrıca gp120, yüzeyinde lgE taşıyan bazofil ve mast hücrelerini de aktive ederek yüksek düzeyde proinflamatuar mediyatör salınımına, dolayısıyla da alerjik reaksiyonlar ve doku hasarının artmasına neden olur. Son yıllarda yapılan bir çalışmada da, Zaire Ebola virusu ile enfekte kişilerde, klinik sonuç ne olursa olsun (ölüm ya da iyileşme), V $\beta 12$, V $\beta 13$ ve V $\beta 17$ TCR taşıyan T hücre popülasyonlarının yok olduğu (anerji veya delesyon) gösterilmiş, bu bulguların da bir SAg varlı̆̆ını işaret ettiği belirtilmiştir. Bu derleme yazıda, SAg'lerin genel özelliklerinden kısaca bahsedilerek, viruslar tarafından kodlanan SAg'ler ve hastalıklardaki rolleri tartışılmaktadır.

Anahtar sözcükler: Virus; süperantijen; T hücre aktivasyonu; TCR V-beta; endojen retroviruslar.

\section{ABSTRACT}

Superantigens (SAgs) are microbial proteins produced by various microorganisms that elicit excessive and strong stimulation of $\mathrm{T}$ cells via an unconventional mechanism. They cause polyclonal activation of T cells in a non-specific manner, by binding to a particular variable-beta $(V \beta)$ chain of T-cell receptor (TCR) and MHC class II molecule, in unprocessed form and outside of peptide-binding cleft, forming a bridge between the antigen presenting cell and the T cell. SAgs are classified into three groups, namely 1) exogenous (soluble proteins and exotoxins secreted by microorganisms), 2) endogenous (transmembrane proteins encoded by viruses which are integrated into the genome) and 3) B-cell SAgs (proteins which stimulate predominantly B cells). The best characterized and mostly studied SAgs are staphylococcal and streptococcal exotoxins, however it is well-known that many other microorganisms also possess SAg activities. Despite the presence of several viruses that cause severe infections in humans, the number of viruses that have proteins identified with SAg property in their pathogenesis, is relatively low. To date, the defined viruses that encoded SAgs are as follows; mouse mammary tumor virus (MMTV) (Marrack, et al. 1991), rabies virus (Lafon, et al. 1992), Epstein-Barr virus (EBV) (Sutkowski, et al. 1996), human endogenous retrovirus (HERV) (Conrad, et al. 1997), human immunodeficiency virus (HIV) (Posnett, et al. 1995; Torres, et al. 1996; Townsley-Fuchs, et al. 1997) and Ebola virus (Leroy, et al. 2011). SAgs were first described in the MMTV, a polymorphic B-type retrovirus that is either contained in the genome as an endogenous provirus (germline transmission) or exogenous infectious virus that transmits vertically via breast milk. Both MMTV forms encode SAgs. The SAg-mediated massive T cell activation is required for the spread of exogenous MMTV from intestines to mammary glands, facilitating the transmission of infectious virus. On the other hand, expression of endogenous SAgs leads to thymic deletion of responding $\mathrm{T}$ cells (bearing $\mathrm{V} \beta 6-9^{+} \mathrm{TCR}$ ) due to self-tolerance induction during the fetal life, and protects the host against future exogenous MMTV infections. The SAg of rabies virus is the $\mathrm{N}$ protein found in nucleocapsid structure and stimulates $V \beta 8^{+} T C R$-bearing $T$ cells. The SAg-induced polyclonal activation of $T$ cells leads to turn-off the specific immune response, to enhance the immunopathogenesis and facilitates viral transmission from the initial site of infection (the muscle tissue) to the nerve endings. In case of EBV-associated SAg that activates V $313^{+} T C R$-bearing $T$ cells, it was detected that the SAg activity was not encoded by EBV itself, but instead was due to the transactivation of HERV-K18 by EBV latent membrane proteins, whose env gene encodes the SAg (Sutkowski, et al. 2001). It has been denoted 
that EBV-induced SAg expression plays a role in the long-term persistence and latency of virus in memory $B$ cells, in the development of autoimmune diseases and in the oncogenesis mechanisms. The proteins which are identified as SAgs of HIV are Nef and gp120. It is believed that, the massive activation of CD4 ${ }^{+}$ $T$ cells (selectively with $V \beta-12^{+}, V \beta-5.3^{+}$and $V \beta-18^{+} T C R s$ ) in early stages of infection and clonal deletion, anergy and apoptosis of bystander T cells in the late stages may be due to SAg property of Nef protein, as well as the other mechanisms. However there are some studies indicating that Nef does not act as a SAg (Lapatschek, et al. 2001). HIV gp120 glycoprotein is a B-cell SAg that binds to VH3-expressing B cell receptors and causes polyclonal B cell activation. In addition, binding of gp120 to IgE on the surface of basophiles and mast cells causes activation of those cells, secretion of high level proinflammatory mediators leading to allergic reactions and tissue damage. In a recent study, the depletion (anergy or deletion) of $\mathrm{T}$ cell populations bearing $\mathrm{V} \beta 12^{+}, \mathrm{V} \beta 13^{+}$and $\mathrm{V} \beta 17^{+} \mathrm{TCR}$ have been shown, in patients infected with Zaire Ebola virus, whatever the clinical outcome (death or recovery), these results also suggest the presence of SAg activity. In this review article, following a brief description of the general characteristics of SAgs, virus-encoded SAgs and their roles in the diseases have been discussed.

Keywords: Virus; superantigen; T cell activation; TCR V-beta; endogenous retroviruses.

\section{Giriş̧}

Süperantijenler, çeşitli mikroorganizmalar tarafından üretilen ve T hücrelerini olağandışı yolla poliklonal olarak aktive eden mikrobiyal proteinlerdir. Süperantijen (SAg) terimi, ilk kez 1989 yılında, T hücrelerini çok güçlü şekilde uyaran bakteriyel toksinler için kullanılmışıır ${ }^{1}$. SAg üretimi, bir mikroorganizmanın virülansını artıran önemli bir faktör olarak kabul edilmektedir ${ }^{2}$. Bu derleme yazıda, SAg'lerin genel özelliklerinden kısaca bahsedilerek, viruslar tarafından kodlanan SAg'ler ve hastalıklardaki rolleri tartışılmıştır.

\section{SÜPERANTIJENLERIN GENEL ÖZELLIKLERI}

Bir antijenin, SAg özelliği göstermesi; T hücre reseptörü (T-cell receptor; TCR) beta zincirinin değişken kısımları (V $\beta$ ) ile antijen sunan hücre (ASH)'lerin yüzeyindeki majör doku uygunluk kompleksi sınıf II (MHC-II) molekülüne dışarıdan, köprü oluşturarak bağlanması ve naif T hücrelerini güçlü ve hızı şekilde aktive etmesine bağlıdır. Süperantijenlerin biyoaktivitesi, hem MHC-II molekülüne hem de TCR'nin belirli bir ya da birkaç V $\beta$ alt tipine bağlanma yeteneği ile belirlenir. Dolayısıyla, her bir SAg'nin karakteristik bir "V $\beta$ imzası" vardır; yani bir SAg, belirli bir veya birkaç TCR V $\beta$ tipine sahip T hücrelerini aktive etmektedir.

Klasik T hücre uyarımı ve aktivasyonu, bilindiği gibi, ASH'ler tarafından alınan ve işlenen (oligopeptidlerine parçalanan) antijenlerin, MHC-II molekülünün kovuğuna yerleştirilerek $C D 4^{+}$yardımcı $T(T H)$ hücrelerine sunulması ve TCR'nin alfa ve beta zincirlerinin değişken ( $V \alpha$ ve $V \beta$ ) bölgeleri tarafından özgül olarak tanınması sonucu gerçekleşir (Şekil 1A). Buna karşın SAg'lerin TH hücrelerini uyarması ve aktive etmesi çok farklı bir şekilde olmaktadır ${ }^{2}$. SAg'ler, ASH'ler tarafından işlenmeye ve sunulmaya gerek duymaksızın, MHC-II molekülünün genellikle $\alpha 1$ kangalı ile ( $\alpha 1+\beta 1^{\prime}$ e çapraz yolla da olabilir) TCR'nin V $\beta$ kısmına dışarıdan, yani özgül olmadan bağlanırlar (Şekil 1B). Dolayısıyla normal bir antijen T hücre popülasyonunun az bir kısmını (\%0.01-0.001) aktive ederken, SAg'ler 


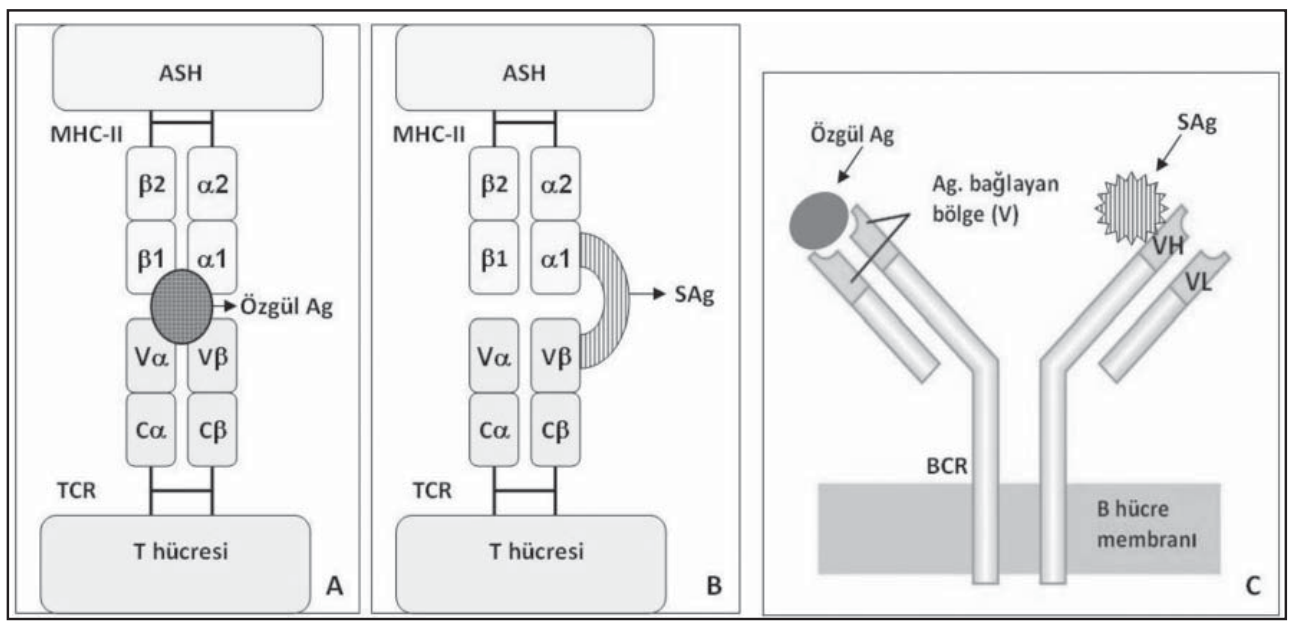

Şekil 1. (A) ASH tarafından TH hücresine normal (özgül) antijen sunumu; (B) SAg'nin TH hücresini aktive etmesi; (C) B hücre SAg'nin B hücresini aktive etmesi. Ag: Antijen; SAg: Süperantijen; ASH: Antijen sunan hücre; MHC: Majör doku uygunluk kompleksi; TCR: T hücre reseptörü; BCR: B hücre reseptörü; V: Değişken bölge; C: Sabit bölge.

çok sayıda T hücre popülasyonunu (\%20-30) özgül olmayan yolla aktive eder ve yüksek düzeylerde sitokin salgılanmasına yol açarlar ${ }^{2-4}$.

Yapısal olarak SAg'ler, 22-29 kD büyüklüğünde globüler proteinler olup iki kangaldan oluşurlar. Amino ucunun olduğu kangal, MHC-II molekülüne; karboksi ucunun olduğu kangal ise TCR'nin V $\beta$ bölgesine bağlanmadan sorumludur. SAg'lerin çoğu 1-2 adet çinko (Zn) bağlayan bölge içerir; bu bölgeler, SAg'lerin MHC-Il molekülleri tarafından tanınmasında etkilidir. SAg'lerin en iyi etkileştiği MHC-II molekülleri, HLA-DR ve HLADQ antijenleridir. SAg'ler, proteazlara ve ısı ile denatürasyona dirençlidirler ve çok düşük konsantrasyonlarda (10 mol/L) etki gösterirler ${ }^{2-4}$.

Süperantijenler; ekzojen, endojen ve B hücre SAg'leri olarak üç grupta sınıflandırılabilir $^{3,4}$. Ekzojen SAg'ler, mikroorganizmalar tarafından salgılanan çözünür proteinler ve ekzotoksinlerdir (Tablo I). Endojen SAg'ler ise, hücre genomuna entegre olmuş viruslar tarafından kodlanan ve hücre membranında bulunan proteinlerdir (Tablo I). Bazı SAg'ler de predominant olarak B hücrelerini uyarırlar (Tablo I). B hücre SAg'leri olarak adlandırılan bu grup, B hücre reseptörünün (yüzeyel IgM; BCR) ağır veya hafif zincirlerinin değişken bölgelerine (sırasıyla; VH ve VL) bağlanır; ancak bu bağlanma da dışarıdan doğru olur ve özgül değildir (Şekil 1C). Böylece B hücrelerinin \%30-60'ının poliklonal aktivasyonu gerçekleşir. Ayrıca, B hücre SAg'lerinin serumdaki çözünür antikorlara (IgM veya lgG) bağlanması sonunda da, büyük miktarlarda immün kompleks (IK) oluşumu gerçekleşir; bu iK'ler komplemanı aktive ederek doku hasarına yol açar$\operatorname{lar}^{4,5}$. B hücre SAg'lerinin, mast hücre ve bazofil yüzeyindeki IgE antikorlarına bağlanması da, proinflamatuar mediyatörlerin yüksek düzeyde salınımına yol açarak doku hasarı ve alerjik reaksiyonların artışına neden olmaktadır. Bu tip SAg'ler "süperallerjen" olarak da anılmaktadır. 


\begin{tabular}{|c|c|c|}
\hline Grup & Mikroorganizma & Altta yatan hastalık* \\
\hline \multirow[t]{21}{*}{ Ekzojen SAg'ler } & \multirow[t]{4}{*}{ Staphylococcus aureus } & Stafilokokal enterotoksinler (SE): A,B,C1-C3, D,E,G-Q \\
\hline & & Stafilokokal toksik şok sendromu toksini (TSST-1) \\
\hline & & Stafilokokal eksfoliatif toksinler (eksfoliatin A ve B) \\
\hline & & Stafilokokal enterotoksin benzeri toksinler: U2, V \\
\hline & \multirow[t]{3}{*}{ Streptococcus pyogenes } & Streptokokal pirojenik ekzotoksinler (SPE): A1-A4, C, G-M \\
\hline & & Streptokokal mitojenik ekzotoksin: SMEZ \\
\hline & & Streptokokal süperantijen: SSA \\
\hline & Streptococcus dysgalactiae & Pirojenik ekzotoksin (A7), S.dysgalactiae kökenli mitojen (SDM) \\
\hline & Streptococcus equi & Pirojenik ekzotoksinler (SePE H, I, L, M) \\
\hline & Yersinia pseudotuberculosis & Y.pseudotuberculosis kökenli mitojen (YAM) \\
\hline & Mycoplasma arthritidis & M.arthritidis kökenli mitojen (MAM) \\
\hline & Pseudomonas aeruginosa & Ekzotoksin A \\
\hline & Vibrio cholerae & Kolera toksini A alt ünitesi \\
\hline & Clostridium perfringens & Enterotoksin \\
\hline & Mycobacterium tuberculosis & TM \\
\hline & Prevotella intermedia & TM \\
\hline & Malassezia furfur & TM \\
\hline & MMTV (enfektif) & Env proteini \\
\hline & Kuduz virusu & Nükleokapsid proteini \\
\hline & HIV & Nef proteini? \\
\hline & Ebola virus & TM \\
\hline \multirow[t]{3}{*}{ Endojen SAg'ler } & MMTV (provirus) & Env geni ürünü \\
\hline & EBV & EBV ile ilişkili SAg \\
\hline & HERV-K18 & Env geni ürünü \\
\hline \multirow[t]{3}{*}{ B hücre SAg'leri } & S.aureus & Stafilokokal protein A (SPA) \\
\hline & HIV & gp120 glikoproteini \\
\hline & Peptostreptococcus magnus & Protein $\mathrm{L}$ \\
\hline
\end{tabular}

EBV: Epstein-Barr virus; HERV: İnsan endojen retrovirusu; HIV: İnsan immün yetmezlik virusu; TM: SAg yapıları tanımlanmamıs.

Süperantijen uyarımı sonucu ortaya çıkan ilk etki; TH hücrelerinin yüksek düzeyde ve kuvvetle prolifere olması, T hücre popülasyonlarının genişlemesi ve büyük miktarlarda proinflamatuvar sitokin [tümör nekrozis faktör (TNF)- $\alpha$, interlökin (IL)-1 $\beta$, IL-2, IL-6, interferon (INF)- $\gamma$, makrofaj inflamatuar protein (MIP)-1 $\alpha$, MIP-1 $\beta$, monosit kemoatraktan protein (MCP)-1] salgılamasıdır". "Sitokin fırtınası" olarak bilinen bu olay, kapiller sızıntının artışı, inflamasyonun artışı, ateş, çoklu organ hasarı ve sistemik şok gelişimine neden olur. Takiben, masif aktivasyonun sonucu olarak $T$ hücrelerinin ölümü (apoptoz) ve delesyonu gerçekleşir, immün süpresyon ortaya çıkar ${ }^{2}$. Ayrıca, T hücre anerjisi sonucu immün tolerans ve oto-reaktif T ve B hücrelerinin aktivasyonu sonucu da otoimmünite gelişebilir. Günümüzde, stafilokokal ve streptokokal toksik şok sendromları, stafilokokal besin zehirlenmesi, stafilokokal haşlanmış deri sendromu, kızıl, Kawasaki 
hastalığı, ekzema, guttat psöriazis, romatoid artrit, diabetes mellitus ve nazal polipler gibi çeşitli hastalıkların SAg üretimi ile ilişkisi bilinmekte; daha birçok enfeksiyon ve hastalıkta da yüksek olası rolleri olduğu ifade edilmektedir ${ }^{2-4,6,7}$. En iyi bilinen ve üzerinde en çok çalışılan SAg'ler, Staphylococcus aureus ve Streptococcus pyogenes tarafından üretilen ekzotoksinlerdir; ancak diğer bazı mikroorganizmaların da SAg aktivitesi mevcuttur (Tablo I) 3,4 .

\section{VIRAL SÜPERANTIJENLER}

Insanda ciddi enfeksiyonlara yol açan çeşitli virusların varlığına rağmen, patogenezinde, SAg özelliği gösteren proteinlerin tanımlandığı virus sayısı görece olarak azdır. Bugüne dek SAg kodladığı belirlenen viruslar; MMTV (1991), kuduz virusu (1992), EBV (1996), insan endojen retrovirusu (1997), HIV (1997) ve Ebola virus (2011) olarak sıralanabilir ${ }^{8-14}$.

\section{Fare Meme Tümörü Virusu (MMTV) ile İlişkili Süperantijen}

Marrack ve arkadaşları ${ }^{8} 1991$ yılında, fare genomunda endojen olarak bulunan MMTV'nin bir SAg kodladığını göstermişlerdir. Daha sonra bu antijenlerin, 1973 yılında Festenstein ${ }^{15}$ tarafından, farelerin timus stromal hücrelerinde keşfedilen "minör lenfosit stimüle edici (Mls) ekzotoksinler" ile aynı olduğu anlaşılmıştı ${ }^{16}$. MMTV tarafından kodlanan SAg, ilk keşfedilen viral SAg olması ve endojen retrovirus SAg'lerinin tanımlanmasında model teşkil etmesi açısından önem taşımaktadır ${ }^{17}$. Bunun yanı sıra, MMTV'nin insan meme kanseriyle ilişkisi olduğuna dair verilerin elde edilmesi, virusun önemini daha da artırmıştır ${ }^{18,19}$. Wang ve arkadaşları ${ }^{18} 1995$ yılında, meme kanseri olan kadınların \%39'unun tümör dokusunda MMTV dizilerine \%95 homoloji gösteren dizilerin varlığını saptamışlar; daha sonra yapılan çalışmalarda da benzer sonuçlar ortaya konmuştur ${ }^{20-22}$. Tüm bu veriler, MMTV'nin insan meme kanserlerindeki rolünün aydınlatılması için ileri çalışmaların yapılması gereğini vurgulamaktadıı ${ }^{23,24}$.

B tipi bir retrovirus olan MMTV, farelerin meme dokusunda bulunur, süt ile bulaşır ve farelerde meme kanserine yol açar. MMTV, ekzojen ve endojen olmak üzere iki formda bulunmaktadır ${ }^{24}$. Ekzojen MMTV replikatif bir virustur ve vertikal geçiş (süt ile) gösterir. Endojen MMTV ise bir provirustur ve kalıtsal yolla Mendel kurallarına göre yavrulara aktarılır. MMTV'nin her iki formu da SAg üretmektedir ${ }^{17}$.

Ekzojen MMTV, süt ile alındıktan sonra bağırsak B hücrelerini enfekte eder ve tipik bir retrovirus gibi replike olur. MMTV'nin kodladığı SAg, 3' LTR (long terminal repeat) bölgesi içinde yer almaktadır ${ }^{17}$. Bu gen ürünü $45 \mathrm{kD}$ büyüklüğünde tip II transmembran proteinidir ve karboksi ucunda, TCR V $\beta$ özgüllüğünden sorumlu, 10-14 aminoasitlik polimorfik bir bölge içermektedir. Transkripsiyon ve translasyon sonrasında sentezlenen SAg, B hücre yüzeyindeki MHC-II'ye bağlanarak uygun TCR V $\beta$ taşıyan TH hücrelerini uyarır (Şekil 2) ${ }^{17}$. TH hücrelerinin masif aktivasyonu, B hücre proliferasyonunun artmasına, dolayısıyla da virusun etkin olarak bağırsak B hücrelerinde çoğalmasına yardımcı olmaktadır. T ve B hücreleri arasındaki bu kuvvetli etkileşim, seçici olarak enfekte $B$ hücrelerinin klonal artışına yol açar. Enfekte B hücrelerinin bir kısmı uzun ömürlü bellek hücrelerine farklılaşır; böylece 


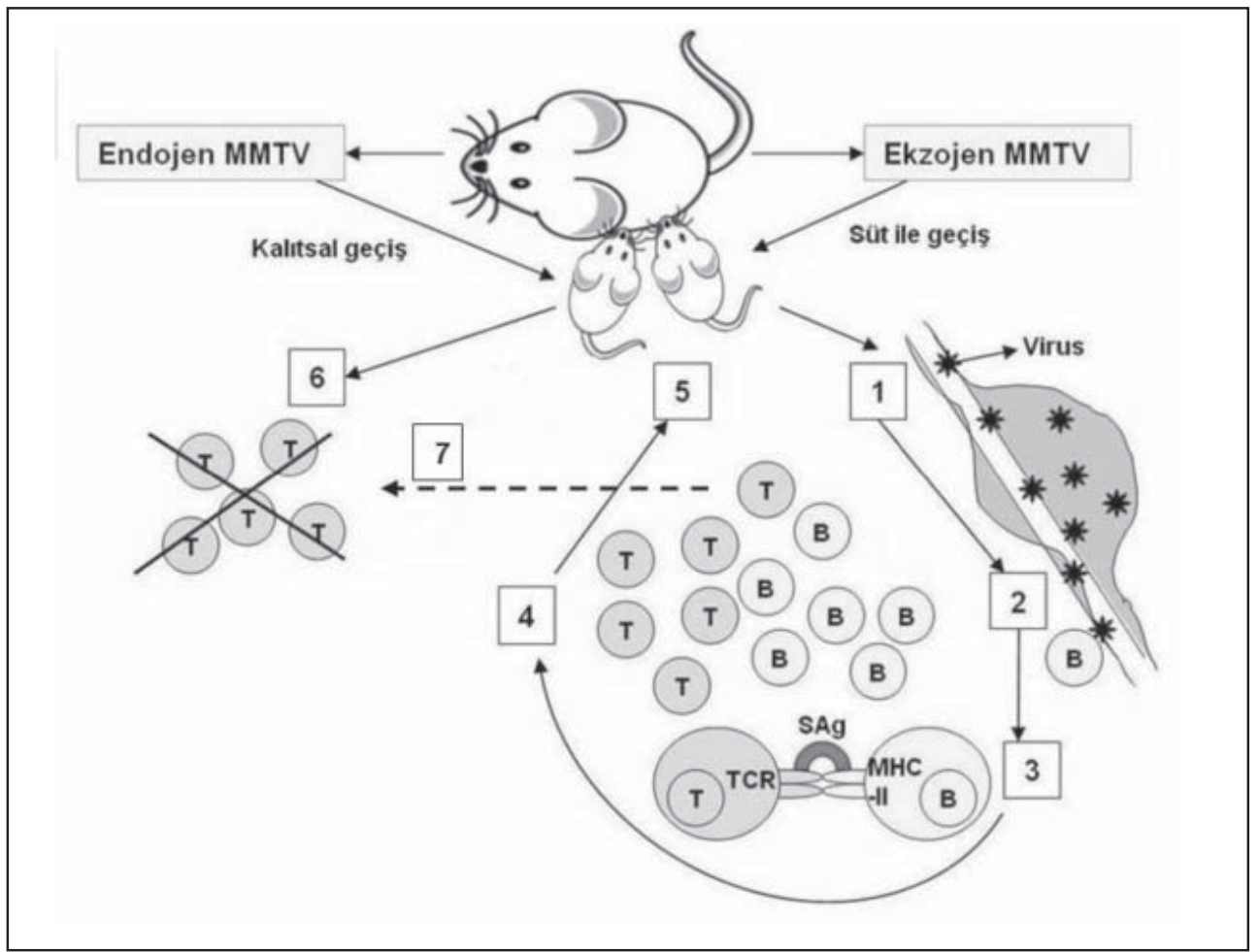

Şekil 2. Ekzojen ve endojen MMTV enfeksiyonları. Ekzojen MMTV enfeksiyonunda, (1) enfekte anneden süt ile yavrulara bulaşan virus mideden geçer, (2) ince bağırsakta B hücrelerini enfekte eder, (3) virusun kodladığı SAg, TH hücrelerini aktive eder, aktive TH hücreleri B hücre aktivasyonunu indükler, (4) böylece enfekte T ve $B$ hücre popülasyonu genişler ve (5) virusun meme bezlerine yayılımı sağlanır. Endojen MMTV enfeksiyonunda ise, (6) yavrulara kalıtsal olarak geçen provirusun kodladığı endojen SAg'ye karşı, fötal hayatta, timusta öz-tolerans gelişir ve bu SAg'yi tanıyan TCR V $\beta$ pozitif T hücreleri delesyona uğrar. (7) Gerek santral gerekse periferal tolerans nedeniyle konakta reaktif $T$ hücrelerinin olmaması, daha sonradan vücuda giren ve aynı tip SAg'yi kodlayan MMTV'nin yayılımını önler (https://www.biosci.utexas.edu/directory/userdetails. aspx?id=1528'den uyarlanmıştır).

MMTV enfeksiyonu stabil hale gelir, meme dokusuna yerleşir ve virus, süt ile salgılanmaya başlar ${ }^{17}$ (Şekil 2). MMTV'nin, bağırsaklardan meme dokusuna yayılımı sırasında, SAg ile uyarılmış T ve B hücrelerinin gerekli olduğu gösterilmiştir ${ }^{25}$. Dolayısıyla MMTV SAg, virusun konakta yayılımı (meme dokusuna ulaşması) için gerekli lenfosit havuzunu artırmaktadır.

Endojen MMTV proviruslarının varlığı ise 1970'li yıllardan beri bilinmekte ve evrimsel süreçte ekzojen virusların fare genomuna rastgele entegrasyonu sonucu ortaya çıktığı düşünülmektedir ${ }^{15,17}$. Bu provirusların çoğu, replike olmak ve enfeksiyöz partikül oluşturabilmek için gerekli temel genlerini kaybetmiş "fosil viruslar"dır; ancak ilginç olarak tümünde SAg genleri (kısmi env ve 3'LTR) bozulmamıştır. Bu genlerin korunmuş olmasının nedeni, konağa seçici avantaj sağlamalarıdır; zira provirus tarafından kodlanan endojen SAg'ler, konağın, enfeksiyöz (ekzojen) MMTV enfeksiyonundan korunmasında önemli rol 
oynarlar $^{26}$. Şöyle ki; anneden yavruya geçen endojen SAg genleri tarafından kodlanan antijenler, fötal dönemde timusta öz (self)-toleransı indüklerler ve bu SAg'yi tanıyan (V $\beta$ 14 TCR taşıyan) T hücrelerinin delesyonuna neden olurlar ${ }^{17,26}$. Böylece, aynı tip SAg'yi kodlayan enfeksiyöz bir virusun konaktaki yayılımı (meme dokusuna ulaşımı), reaktif T hücrelerinin olmaması nedeniyle mümkün olmayacak ve konak, ekzojen MMTV enfeksiyonundan korunmuş olacaktır ${ }^{17}$ (Şekil 2). Dolayısıyla, diğer çoğu mikroorganizmanın konak immün sistemini bozmak amacıyla kullandığı SAg'lerin aksine, MMTV, yaşamı için SAg tarafından indüklenmiş kuvvetli bir konak immün yanıtına gereksinim duymaktadır.

\section{Kuduz Virusu ile Iilişkili Süperantijen}

Zarflı, negatif tek iplikli bir RNA virusu olan kuduz virusu, nükleoprotein (N), fosfoprotein (NS), RNA polimeraz (L), matriks proteini (M) ve yüzey proteini (G) olmak üzere beş adet protein kodlamaktadır. N, NS ve L proteinleri virusun nükleokapsidini oluşturur. Nükleokapsid yapısında bulunan N proteininin, ekzojen bir SAg olduğu gösterilmiştir ${ }^{9}$. Fosforillenmiş bir protein olan N proteini, 450 aminoasitten oluşur ve hücrenin enfeksiyonu sırasında bol miktarda sentezlenir. $\mathrm{N}$ proteini, olgun virionda heliksel nükleokapsidin majör bileşeni olup, replikasyon, transkripsiyon ve morfogenez sırasında rol oynamaktadır. Kuduz virusunun SAg'si, MHC-II $\alpha 1$ zinciri ve TCR V $\beta 8$ 'e bağlanarak T hücrelerini uyarmaktadır ${ }^{9,17}$. Bunun sonucunda oluşan poliklonal T hücre aktivasyonu, özgül immün yanıtın kapatılmasına, virusun ilk enfeksiyon bölgesinden (kas dokusu) sinir uçlarına geçişinin kolaylaşmasına ve immünopatogenezin artışına neden olmaktadır. Sinir sistemine geçişin kolaylaştırılması ile ilgili mekanizma tam olarak aydınlatılamamış olmakla birlikte, SAg ile yüksek düzeyde uyarılan T hücrelerinin salgıladığı sitokinlerle ilişkili olduğu düşünülmektedir. Nitekim, TNF- $\alpha$ ve IL-1 $\beta$ gibi proinflamatuvar sitokinlerin, virusun reseptörlerinden olan nöronal nikotinik asetilkolin reseptörü (nAchR) ekspresyonunu artırdığı gösterilmiştir ${ }^{27}$. Farelerde yapılan çalışmalarda, SAg ile uyarılmış T hücreleri ortadan kaldırılığında, virusun sinirlere geçişinin azaldığı gösterilmiş; ayrıca N proteini ile yapılan immünizasyonun yüksek düzeyde koruyucu olduğu saptanmıştır ${ }^{28}$.

\section{Epstein-Barr virus (EBV) ile Iilişkili Süperantijen}

Herpesviridae ailesinin bir üyesi olan EBV, tüm dünyada yaygın olarak bulunmaktadır. Yetişkinlerin \%90'ından fazlası EBV ile latent olarak enfektedir. Çocukluk döneminde kazanılan enfeksiyonlar büyük oranda asemptomatik seyretmekle birlikte, adölesan ve genç erişkin dönemde kazanılan enfeksiyonlar enfeksiyöz mononükleoz (EM) tablosuyla seyretmektedir. EM, yoğun B ve T hücre aktivasyonu ile karakterize, kendini sınırlayan lenfoproliferatif bir hastalıktır. Buna karşın, immün sistemi baskılanmış hastalarda EBV'nin reaktivasyonu çeşitli kanserler ile ilişkilidir. Bu bilgiler ışığında, EBV'nin bir SAg aktivitesine sahip olup olmadığını araştıran Sutkowski ve arkadaşları ${ }^{10}, 1996$ yılında yayınlanan çalışmalarında, EBV ile transforme $B$ hücre dizilerinin, V $\beta 13$ TCR taşıyan T hücrelerini seçici olarak uyardığını ve B hücrelerinde SAg ekspresyonunun, EBV'nin litik döngüye geçişinin indüksiyonu ile ilişkili olduğunu göstermişlerdir. Ancak aynı araştırıcıların yaptığı ileri çalışmalarda, bu SAg aktivitesinin EBV'nin kendisi tarafından değil, transaktive ettiği, HERV-K18 olarak adlandırılan endojen bir retrovirus tarafından kodlandığı orta- 
ya konmuştur ${ }^{29}$. Bu noktada, insan endojen retroviruslarından kısaca bahsetmek gereği doğmaktadır.

\section{Insan Endojen Retrovirusları (Human Endogenous Retrovirus; HERV)}

Insan Genom Projesi çalışmaları sırasında, insan genomuna entegre olarak bulunan provirusların varlığı tespit edilmiş ve bunların insan endojen retrovirus (HERV) dizileri olduğu tanımlanmıştır ${ }^{30}$. HERV dizileri, insan genomunun yaklaşık \%8'ini oluşturmaktadır. HERV dizilerinin, evrimsel olarak, milyonlarca yıl önce, atasal (germline) hücrelere entegre olan enfeksiyöz retroviruslardan köken aldığı ve Mendel kurallarına göre aktarılarak insan popülasyonlarında kalıcı hale geldiği düşünülmektedir ${ }^{30,31}$.

Üç büyük sınıfta (I, II ve III) gruplandırılan HERV'ler çok sayıda aileye (K, L, W, H, T, vb) ayrılmışlardır. Bunlar içinde en genç ve en aktif olan grup HERV-K ailesidir ${ }^{32}$. Bu grupta yer alan HERV-K18'in SAg aktivitesine sahip olduğu, ilk kez 1997 yılında, insüline bağımlı diyabeti olan hastalarda tanımlanmış ve bu virus, IDDMK ${ }_{1,2} 22$ (Insulin Dependent Diabetes Mellitus-associated $\mathrm{K}$ virus) olarak adlandırılmıştır ${ }^{11}$. Conrad ve arkadaşları ${ }^{11}$, diyabetli hastaların pankreas adacıklarında yoğun V $\beta$-7 TCR taşıyan T hücre infiltrasyonu olduğunu ve SAg ile aktive olan bu hücrelerin pankreas hücrelerini hasara uğrattığını göstermişlerdir. IDDMK ${ }_{1,2} 22$ virusunun, daha sonra, HERV-K18'in alelik bir varyantı olduğunu belirlenmiş ve çoğunlukla V $\beta 13$, daha az olarak da V $\beta 7$ TCR taşıyan T hücreleri üzerinde mitojenik aktivite gösterdiği bildirilmiştir ${ }^{33}$.

HERV'ler, ekzojen retroviruslar gibi gag, po/ ve env genlerini içerirler, ancak bu genlerin bazıları delesyonlar ve insersiyonlar nedeniyle defektif hale gelmiş olabilir. Buna karşın LTR bölgeleri bozulmamıştır ${ }^{31,33}$. HERV genleri, histon metilasyonu gibi konak faktörleri tarafından baskılanmış durumdadır. Ancak çeşitli faktörlere bağlı olarak bu baskının kalkması, genin aktif hale gelmesine ve fonksiyonel proteinleri kodlamasına yol açmaktadır. Bugün için nedeni bilinmeyen birçok hastalıktan, HERV genlerinin aktivasyonu sorumlu tutulmaktadır ${ }^{34}$. Bunlar arasında; özellikle HERW-W grubunun, başta multiple skleroz ve şizofreni olmak üzere çeşitli nörolojik ve otoimmün hastalıklarla; HERV-K grubunun ise çeşitli kanserlerle ilişkili olabileceği ifade edilmektedir ${ }^{32,35-38}$.

\section{HERV-K18'in EBV Tarafindan Transaktivasyonu}

HERV-K18 dizisi, insanda 1. kromozomda, CD48 geninin ilk intronunda yer alır ve başlangıç kısmında EBV'nin indüklediği bir artırıcı (enhancer) bölgeye sahiptir ${ }^{33}$ (Şekil 3). Bu bölge, EBV'nin latent membran proteinleri (özellikle LMP-2A ve LMP-1) tarafından aktive edilmektedir $^{33,39}$. Böylece, normalde sessiz olarak bulunan HERV-K18 provirusunun env geni, EBV LMP'lerin neden olduğu transkripsiyonel aktivasyon sonucunda SAg sentezlemeye başlar (Şekil 3). EBV'nin indüklediği SAg üretiminin, virusun latent olarak kalmasında ve ayrıca otoimmün hastalıklar ve onkogenez mekanizmalarında rol oynadığı düşünülmektedir $^{33}$.

Bilindiği gibi EBV, immün sistemden kaçarak yaşamını sürdürmek ve konakta kalıcı olabilmek için bellek B hücrelerinde latent döneme girmektedir. EBV ile aktive olan 
B hücrelerinin ise bellek B hücrelerine farklılaşması için, TH hücre yardımı gereklidir. Işste bu noktada, EBV'nin transaktive ettiği SAg üretimi, TH hücrelerini yüksek düzeyde uyararak, EBV ${ }^{+}$lenfoblastların bellek hücrelerine dönüşmesini sağlar; böylece EBV'nin bellek B hücrelerindeki latentliği kolaylaşır ve artırılır (Şekil 3). EBV ile ilişsili kanserlerde ise, $\mathrm{EBV}^{+}$tümör hücrelerinde LMP-1 ve LMP-2A ekspresyonunun arttığı bilinmektedir. Bu proteinlerin düzeyindeki artış, HERV-K18 env geni yani SAg'nin sentezini de artıracaktır. Üretilen SAg'ler tarafından indüklenen T hücrelerinin, EBV ile ilişkili kanserlerde metastazın artışında rol oynadığı; salgılanan sitokin ve kemokinlerle mikroçevreyi değiştirerek tümör hücrelerinin sitotoksik T hücrelerinden kaçışını kolaylaştırdığı ifade edilmektedir ${ }^{17,33}$ (Şekil 3).

Herpesviridae ailesinin bir diğer üyesi olan sitomegalovirus (CMV) da, EBV'ye benzer özellikler göstermektedir. Toplumlarda çok yaygın olarak bulunan CMV, EBV gibi, erken

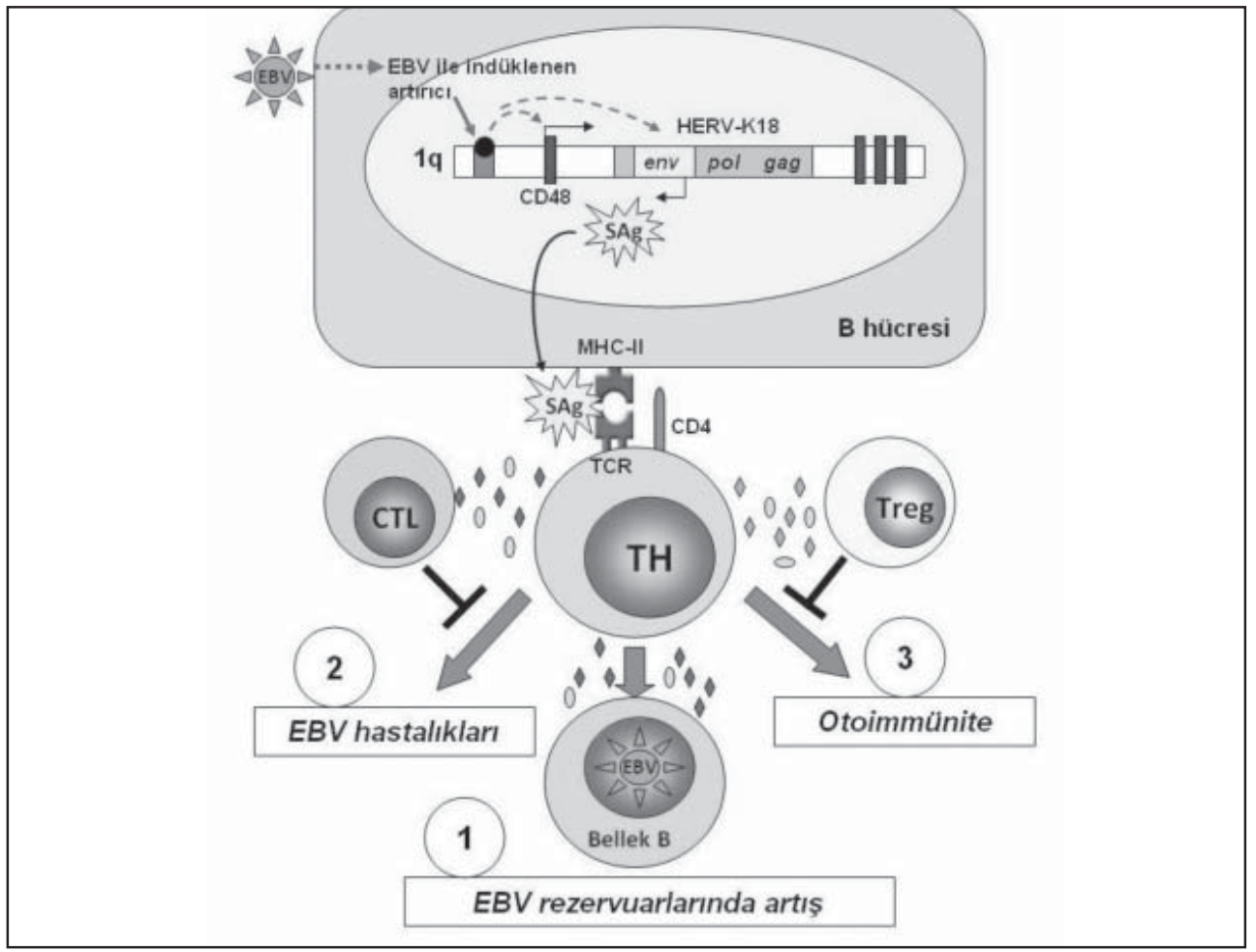

Şekil 3. HERV-K18 env geninin EBV tarafından transaktivasyonu ve sonuçları. EBV, B hücrelerinde HERV-K18 SAg ekspresyonunu indükler, lokalize TH hücre uyarımına yol açar. 1) Yoğun TH uyarımı ile EBV + lenfoblastların bellek $B$ hücrelerine dönüşümü artar; EBV rezervuar olarak kullandığı bellek B hücre kompartmanına yerleştikten sonra, sağıklı konakta $T$ hücre aktivasyonu kendini sınırlar. 2) immün süpresif konakta, virusa özgül bellek sitotoksik T lenfositleri (CTL) baskılandığı için, SAg ile aktive olan TH hücreleri ve yoğun sitokin üretimi lenfoproliferatif hastalıklara neden olur. 3) Bir diğer olasılık, EBV ile indüklenen SAg'lerin, otoreaktif TH hücrelerini doğrudan aktive ederek veya sitokinlerle regülatör T (Treg) hücrelerini baskılayarak otoimmüniteyi tetiklemesidir (http://sackler.tufts.edu/Faculty-and-Research/Faculty-Research-Pages/Brigitte-Huber'den uyarlanmıştır). 
çocukluk döneminde kazanılır, sıklıkla asemptomatik seyreder ve primer enfeksiyonun adölesan dönemde geçirilmesi, masif T hücre proliferasyonu ile karakterize EM benzeri semptomlara yol açar. EBV'nin bir ASH olan B hücrelerini enfekte etmesine karşın, CMV başka bir ASH grubunu, monositleri enfekte etmektedir. Dolayısıyla bu iki herpesvirus, konakta benzer immünolojik reaksiyonlar oluşturmaktadır. Bu noktadan hareketle, CMV'nin SAg aktivitesi ile ilgili çalışmalar yapılmış; konu ile ilgili veriler, AIDS'li hastalarda yapılan çalışmalardan elde edilmiştir. Dubrescu ve arkadaşları ${ }^{40,41}$, CMV seropozitif, HIV ile enfekte hastalarda, HIV-1 replikasyonunun V $\beta 12$ TCR taşıyan T hücrelerinde daha fazla olduğunu, CMV seronegatif yenidoğanlarda ise olmadığını gözlemlemişler ve bu durumu in vitro deneylerle de göstermişlerdir. Araştırıcılar, HIV enfeksiyonu sırasında reaktive olan $C M V^{\prime}$ nin bir SAg kodlayarak $V \beta 12^{+} \mathrm{T}$ hücrelerini uyardığını ve böylece aktive olan T hücrelerinin, enfekte kişilerde yıllar boyunca HIV-1 için rezervuar görevi gördüğünü ifade etmişlerdir ${ }^{41}$. Ancak bugün için, CMV'de SAg kodlayan bir gen bölgesi tanımlanmamıştır.

\section{HIV ile iliş̧kili Süperantijenler}

İnsan immün yetmezlik virusu (HIV), bilindiği gibi, konağın immün yanıtından başarıyla kaçmanın yanı sıra, immün sisteme karşı koyan ve onu çökerten sofistike mekanizmalara sahiptir. Tüm bu mekanizmaların arasında, SAg özelliği gösteren HIV proteinlerinin varlığı da beklenen bir durumdur. Nitekim, HIV'in aksesuvar proteini olan Nef ve zarf glikoproteini olan gp120'nin SAg özelliğine sahip olduğu bildirilmiştir ${ }^{42}$.

HIV'in Nef proteini, viral replikasyonun artışı, enfektivitenin artışı, T hücre aktivasyonu, CD4 ve MHC-I moleküllerinin inhibisyonu ve sitotoksik $T$ hücrelerinin apoptozu gibi birçok etkiye sahip önemli bir virülans faktörüdür ${ }^{43}$. Nef'in sebep olduğu $T$ hücre aktivasyonunun, SAg özelliğine bağlı olabileceği düşünülmektedir. Nef, enfeksiyonun erken döneminde, M-tropik HIV ile enfekte makrofajlardan salınmakta ve seçici olarak $\mathrm{V} \beta 5,8,12-18 \mathrm{TCR}$ taşıyan $\mathrm{CD} 4^{+} \mathrm{T}$ hücrelerini aktive etmektedir ${ }^{12,44}$. Böylece dinlenme halindeki $\mathrm{CD}^{+} \mathrm{T}$ hücrelerinin masif aktivasyonu ve proliferasyonu gerçekleşmekte; yani virus, replike olabilmek için kendisine bol miktarda aktive T hücre havuzu oluşmaktadır ${ }^{45}$. Enfeksiyonun ileri dönemlerinde ise, T hücrelerinde klonal delesyon, anerji ve enfekte olmayan (bystander) T hücrelerinin apoptozu ortaya çıkar. AIDS'de ortaya çıkan klinik semptomların bireysel farklılıklar göstermesinin, TCR V $\beta$ gen polimorfizmlerine ve MHCIl alellerinin SAg'e karşı afinitesindeki farklılıklara bağlı olduğu düşünülmektedir ${ }^{42}$. Buna karşın Lapatschek ve arkadaşları ${ }^{46}$, Nef'in fonksiyonel olarak SAg gibi davranmadığını ileri sürmektedir.

HIV'in gp120 proteini ise bir B hücre SAg olup, B hücre reseptörlerine (BCR) ve serum immünoglobulinlerine olağandışı şekilde bağlanmaktadır ${ }^{47}$. Fonksiyonel olarak gp120, özellikle VH3 eksprese eden B hücrelerini uyarır. BCR'ye bağlanma poliklonal B hücre aktivasyonuna neden olurken, serbest antikorlara bağlanma büyük miktarda immün kompleks oluşumuna ve kompleman aktivasyonuna yol açarak doku hasarı oluşturur. Yapılan çalışmalar, bağlanmanın, gp120'nin V4 bölgesi ile VH3 immünoglobulin gen ailesinin çok değişken kısmı (CDR-2) arasında olduğunu göstermiştir ${ }^{48}$. HIV enfeksiyonu sırasında VH3 B hücrelerinde yüksek düzeyde bir aktivasyon söz konusu iken, tipik bir SAg etkisi olarak, AIDS'e ilerleyen hastalarda bu hücreler delesyona uğramakta ve yok olmaktadır ${ }^{13,47}$. 
HIV-1 enfeksiyonu sırasında, hastalarda serum IgE düzeyleri yükselmekte ve bu durum kötü prognozu işaret etmektedir. Marone ve arkadaşları ${ }^{49}$, gp120'nin bir SAg gibi davranarak, yüzeyinde $\mathrm{Fc \varepsilon RI}$ reseptörüne bağlı lgE taşıyan bazofil ve mast hücrelerini aktive ettiğini ve histamin ve sitokin (IL-4 ve IL-13) salınımını artırdığını göstermişlerdir. $\mathrm{Bu}$ sitokinler, ya doğrudan $\mathrm{B}$ hücrelerini aktive ederek ya da $\mathrm{TH}$ hücrelerini $\mathrm{TH} 2$ yönüne çevirmek suretiyle $B$ hücrelerinin aktivasyonuna yol açarak yüksek düzeyde lgE sentezine neden olmaktadır ${ }^{49}$. Sonuçta, gerek proinflamatuar mediyatörlerin gerekse lgE düzeylerinin artışı, alerjik reaksiyonlara ve doku hasarına yol açmaktadır.

\section{Ebola Virus Süperantijeni}

Ebola virusu, özellikle de Zaire suşu (ZEBOV), \%90'a varan mortalite ile seyreden hemorajik ateşe neden olmaktadır. Bu enfeksiyonlar, hastalarda zayıf immün yanıt ve şiddetli inflamatuar reaksiyon ile karakterizedir ${ }^{50}$. İmmün yanıt yetersizliğine yol açan faktörlerden birisi, masif $\mathrm{CD}^{+}$ve $\mathrm{CD}^{+} \mathrm{T}$ hücre apoptozunun virus tarafından indüklenmesidir; oysa ZEBOV lenfositleri enfekte etmemektedir. Sitokin fırtınası ile karakterize anormal immün yanıt ve fatal enfeksiyonlarda toksik şok sendromu benzeri tablonun ortaya çıkması, diğer birçok mekanizmanın yanı sıra ZEBOV'un bir SAg aktivitesine sahip olabileceğini düşündürmektedir. SAg varlığının araştırmasına yönelik olarak, Leroy ve arkadaşlarının ${ }^{14}$ yaptığı çalışmada, ZEBOV'un neden olduğu 1996 Gabon salgınında, virustan etkilenen kişilerde (hastalıktan ölenler, hastalıktan iyileşenler ve asemptomatik temaslılar), TCR V $\beta$ repertuvarı, ters transkripsiyon-polimeraz zincir reaksiyonu (RT-PCR) ile araştırılmıştır. Çalışmanın sonucunda, tüm olgu gruplarında, kontrollerle karşılaştırıldığında, TCR V $\beta 12$, V $\beta 13$ ve V $\beta 17$ taşıyan $T$ hücre popülasyonlarında ciddi azalmanın olduğu tespit edilmiştir. Bu araştırıcılar, klinik sonuç ne olursa olsun, ZEBOV ile enfekte kişilerde belirli TCR V $\beta$ tiplerini taşıyan T lenfositlerinde anerji veya delesyonun olduğunu, bu bulguların da bir SAg varlığını işaret ettiğini belirtmişlerdir ${ }^{16}$. SAg aktivitesinin, virusun çözünür zarf glikoproteinlerine bağlı olma olasılığına rağmen, bu konu henüz açık değildir. Yapılan literatür taramasında, ulaşılabildiği kadarıyla, Ebola virus SAg'i konusunda başka bir çalışmaya rastlanmamıştır.

\section{SONUÇ}

Süperantijenler, sentezlendikleri mikroorganizmanın patojenitesini artırmanın yanı sıra, konağa karşı patojenin immünolojik bir üstünlük kazanmasını sağlamaktadırlar. Günümüzde, SAg'lerin, önceden beri iyi bilinen klasik hastalıkların (örn. toksik şok sendromu, haşlanmış deri sendromu) dışında, alerjik, nörolojik ve otoimmün hastalıklar, inflamatuar deri hastalıkları, immün yetmezlikler ve hatta bazı kanserler de dahil olmak üzere birçok patolojiden sorumlu olduğu anlaşılmıştır. Viral SAg'ler ile ilgili çalışmalar ise, özellikle insan genomunda bulunan endojen retrovirusların tanımlanması ve bunların env genleri ve LTR bölgelerinin SAg sentezinden sorumlu olduğunun gösterilmesiyle hız kazanmıştır. Vücudumuzda normalde sessiz olarak bulunan HERV dizilerinin, başka bir patojen (örn. EBV) ya da diğer mekanizmalarla transaktive olma olasılığının, otoimmünite ve onkogenez açısından potansiyel bir risk oluşturduğu düşünülmektedir. Dolayısıyla, ileriki yıllarda yapılacak olan çalışmalarda, gerek enfeksiyöz virusların gerekse endojen retrovirusların kodladığı SAg özelliğine sahip proteinlerin tanımlanması, hastalıkların patofizyolojisinin aydınlatılmasında yol gösterici olacaktır. 


\section{KAYNAKLAR}

1. Choi YW, Kotzin B, Herron L, Callahan J, Marrack P, Kappler J. Interaction of Staphylococcus aureus toxin "superantigens" with human T cells. Proc Natl Acad Sci U S A 1989; 86(22): 8941-5.

2. Vaishnani J. Superantigen. Indian J Dermatol Venereol Leprol 2009; 75(5): 540-4.

3. Hemalatha V, Srikanth P, Mallika M. Superantigens - concepts, clinical disease and therapy. Indian J Med Microbiol 2004; 22(4): 204-11.

4. Solanki LS, Srivastava N, Singh S. Superantigens: a brief review with special emphasis on dermatologic diseases. Dermatol Online J 2008; 14(2): 3.

5. Zouali M. B cell superantigens subvert innate functions of B cells. Chem Immunol Allergy 2007; 93:92-105.

6. Torres BA, Kominsky S, Perrin GQ, Hobeika AC, Johnson HM. Superantigens: the good, the bad, and the ugly. Exp Biol Med (Maywood) 2001; 226(3): 164-76.

7. Sur G, Sporis D, Kudor-Szabadi L, Samasca G. Super-antigens and human pathology: always an interesting topic. J Bioequiv Availab 2013; 5(3): 125-8.

8. Marrack P, Kushnir E, Kappler J. A maternally inherited superantigen encoded by a mammary tumour virus. Nature 1991; 349(6309): 524-6.

9. Lafon M, Lafage M, Martinez-Arends A, et al. Evidence for a viral superantigen in humans. Nature 1992; 358(6386): 507-10.

10. Sutkowski N, Palkama T, Ciurli C, et al. An Epstein-Barr virus-associated superantigen. J Exp Med 1996; 184(3): 971-80.

11. Conrad B, Weissmahr RN, Böni J, et al. A human endogenous retroviral superantigen as candidate autoimmune gene in type I diabetes. Cell 1997; 90(2): 303-13.

12. Posnett DN, Kabak S, Dobrescu D, Hodtsev AS. The HIV-1 reservoir in distinct V beta subsets of CD4 T cells: evidence for a putative superantigen. J Clin Immunol 1995; 15(6 Suppl): 18S-21S.

13. Townsley-Fuchs J, Neshat MS, Margolin DH, Braun J, Goodglick L. HIV-1 gp120: a novel viral B cell superantigen. Int Rev Immunol 1997; 14(4): 325-38.

14. Leroy EM, Becquart P, Wauquier N, Baize S. Evidence for Ebola virus superantigen activity. J Virol 2011; 85(8): 4041-2.

15. Festenstein $\mathrm{H}$. Immunogenetic and biological aspects of in vitro lymphocyte allotransformation (MLR) in the mouse. Transplant Rev 1973; 15: 62-88.

16. Beutner U, Rudy C, Huber BT. Molecular characterization of Mls-1. Int Rev Immunol 1992; 8(4): $279-88$.

17. Huber BT, Hsu PN, Sutkowski N. Virus-encoded superantigens. Microbiol Rev 1996; 60(3): 473-82.

18. Wang Y, Holland JF, Bleiweiss IJ, Melana S, et al. Detection of mammary tumor virus env gene-like sequences in human breast cancer. Cancer Res 1995; 55(22): 5173-9.

19. Pogo BG, Holland JF. Possibilities of a viral etiology for human breast cancer. A review. Biol Trace Elem Res 1997; 56(1): 131-42.

20. Etkind P, Du J, Khan A, Pillitteri J, Wiernik PH. Mouse mammary tumor virus-like ENV gene sequences in human breast tumors and in a lymphoma of a breast cancer patient. Clin Cancer Res 2000; 6(4): $1273-8$.

21. Wang Y, Pelisson I, Melana SM, Go V, Holland JF, Pogo BG. MMTV-like env gene sequences in human breast c ncer. Arch Virol 2001; 146(1): 171-80.

22. Holland JF, Pogo BG. Mouse mammary tumor virus-like viral infection and human breast cancer. Clin Cancer Res 2004; 10(17): 5647-9.

23. Salmons B, Gunzburg WH. Revisiting a role for a mammary tumor retrovirus in human breast cancer. Int J Cancer 2013; 133(7): 1530-5.

24. Holt MP, Shevach EM, Punkosdy GA. Endogenous mouse mammary tumor viruses (mtv): new roles for an old virus in cancer, infection, and immunity. Front Oncol 2013; 3:287.

25. Golovkina TV, Dudley JP, Ross SR. B and T cells are required for mouse mammary tumor virus spread within the mammary gland. J Immunol 1998; 161(5): 2375-82. 
26. Golovkina TV, Chervonsky A, Dudley JP, Ross SR. Transgenic mouse mammary tumor virus superantigen expression prevents viral infection. Cell 1992; 69(4): 637-45.

27. Gahring LC, Days EL, Kaasch T, et al. Pro-inflammatory cytokines modify neuronal nicotinic acetylcholine receptor assembly. J Neuroimmunol 2005; 166(1-2): 88-101.

28. Lafon M. Viral superantigens. Rev Med Interne 2000; 21(8): 713-6.

29. Sutkowski N, Conrad B, Thorley-Lawson DA, Huber BT. Epstein-Barr virus transactivates the human endogenous retrovirus HERV-K18 that encodes a superantigen. Immunity 2001; 15(4): 579-89.

30. Griffiths DJ. Endogenous retroviruses in the human genome sequence. Genome Biol 2001; 2(6): REVIEWS1017.

31. Kim HS. Genomic impact, chromosomal distribution and transcriptional regulation of HERV elements. Mol Cells 2012; 33(6): 539-44.

32. Hohn O, Hanke K, Bannert N. HERV-K(HML-2), the best preserved family of HERVs: endogenization, expression, and implications in health and disease. Front Oncol 2013; 3:246.

33. Sutkowski N, Huber BT. EBV induces an endogenous superantigen: Implications for pathogenesis, pp: $233-$ 62. In: Robertson ES (ed), Epstein-Barr Virus. 2005, Caister Academic Press, England.

34. Suntsova M, Garazha A, Ivanova A, et al. Molecular functions of human endogenous retroviruses in health and disease. Cell Mol Life Sci 2015; 72(19): 3653-75.

35. Brodziak A, Ziolko E, Muc-Wierzgon $M$, et al. The role of human endogenous retroviruses in the pathogenesis of autoimmune diseases. Med Sci Monit 2012; 18(6): RA80-8.

36. Emmer A, Staege MS, Kornhuber ME. The retrovirus/superantigen hypothesis of multiple sclerosis. Cell Mol Neurobiol 2014; 34(8): 1087-96.

37. Downey RF, Sullivan FJ, Wang-Johanning F, Ambs S, Giles FJ, Glynn SA. Human endogenous retrovirus K and cancer: Innocent bystander or tumorigenic accomplice? Int J Cancer 2015; 137(6): 1249-57.

38. Christensen T. Human endogenous retroviruses in neurologic disease. APMIS 2016; 124(1-2): 116-26.

39. Sutkowski N, Chen G, Calderon G, Huber BT. Epstein-Barr virus latent membrane protein LMP-2A is sufficient for transactivation of the human endogenous retrovirus HERV-K18 superantigen.J Virol 2004; 78(14): 7852-60.

40. Dobrescu D, Kabak S, Mehta K, et al. Human immunodeficiency virus 1 reservoir in CD4+ T cells is restricted to certain V beta subsets. Proc Natl Acad Sci U S A 1995; 92(12): 5563-7.

41. Dobrescu D, Ursea B, Pope M, Asch AS, Posnett DN. Enhanced HIV-1 replication in V beta 12 T cells due to human cytomegalovirus in monocytes: evidence for a putative herpesvirus superantigen. Cell 1995; 82(5): 753-63.

42. Torres BA, Tanabe T, Subramaniam PS, Yamamoto JK, Johnson HM. Mechanism of HIV pathogenesis: role of superantigens in disease. Alcohol Clin Exp Res 1998; 22(5 Suppl): 188S-192S.

43. Basmaciogullari S, Pizzato M. The activity of Nef on HIV-1 infectivity. Front Microbiol 2014; 5:232.

44. Tanabe T, Torres BA, Subramaniam PS, Johnson HM. V beta activation by HIV Nef protein: detection by a simple amplification procedure. Biochem Biophys Res Commun 1997; 230(3): 509-13.

45. Torres BA, Tanabe T, Yamamoto JK, Johnson HM. HIV encodes for its own CD4 T-cell superantigen mitogen. Biochem Biophys Res Commun 1996; 225(2): 672-8.

46. Lapatschek MS, Dürr S, Sutter G, Wagner H, Miethke T. Functional evaluation of HIV/SIV Nef as superantigen. Virology 2001; 282(2): 329-37.

47. Müller S, Köhler H. B cell superantigens in HIV-1 infection. Int Rev Immunol 1997; 14(4): 339-49.

48. Neshat MN, Goodglick L, Lim K, Braun J. Mapping the B cell superantigen binding site for HIV-1 gp120 on a V(H)3 Ig. Int Immunol 2000; 12(3): 305-12.

49. Marone G, Florio G, Petraroli A, de Paulis A. Dysregulation of the IgE/Fc epsilon RI network in HIV-1 infection. J Allergy Clin Immunol 2001; 107(1): 22-30.

50. Wauquier N, Becquart P, Padilla C, Baize S, Leroy EM. Human fatal zaire ebola virus infection is associated with an aberrant innate immunity and with massive lymphocyte apoptosis. PLoS Negl Trop Dis 2010; 4(10). pii: e837. 